\title{
ASSESSMENT OF VARIOUS WATER-GAS-SHIFT PROCESS CONFIGURATIONS APPLIED TO PARTIAL OXIDATION ENERGY CONVERSION PROCESSES WITH CARBON CAPTURE
}

\author{
VLAD-CRISTIAN SANDUa, CALIN-CRISTIAN CORMOS ${ }^{a}$, \\ ANA-MARIA CORMOS ${ }^{a^{*}}$
}

\begin{abstract}
The energy conversion systems based on partial oxidation processes (hydrocarbons catalytic reforming, solid fuel gasification) are very promising for integrating carbon capture technologies due to high $\mathrm{CO}_{2}$ partial pressure in syngas to be treated. In these systems, the water-gas-shift (WGS) reaction has a very important place in concentrating the syngas energy as hydrogen and to convert carbon species as $\mathrm{CO}_{2}$. This paper is evaluating various WGS process configurations to be applied in catalytic reforming and gasification designs ranging from the conventional designs (multiple catalytic shift reactors) to more innovative reactive gas-solid systems (chemical \& calcium looping) for simultaneous syngas conversion and $\mathrm{CO}_{2}$ capture. As the evaluations show, the reactive gas-solid systems are more promising in reducing energy penalty for $\mathrm{CO}_{2}$ capture as well as to increase the overall energy efficiency and carbon capture rate. As illustrative examples, the coal gasification for hydrogen and power co-generation with carbon capture were assessed.
\end{abstract}

Keywords: Partial oxidation, Water-gas-shift, Carbon capture, Reactive gasliquid and gas-solid systems.

\section{INTRODUCTION}

The fossil fuel intensive industrial applications are facing increasing pressure from the point of reducing greenhouse gas (GHG) emissions as well as to secure primarily energy supplies [1]. In the last decade, significant research and development efforts were directed to reduce GHG emissions (in combating

\footnotetext{
a Babeş-Bolyai University, Faculty of Chemistry and Chemical Engineering, 11 Arany Janos str., RO-400028, Cluj-Napoca, Romania

*Corresponding author: cani@chem.ubbcluj.ro
} 
global warming and climate change) and also to find promising energy conversion systems with higher energy efficiency. Along this line, a large variety of conceptual methods can be used e.g. replacing fossil fuels (natural gas, coal, lignite) with renewable energy sources (solar, wind, biomass) as energy carriers, increasing the energy efficiency of large scale industrial systems, improving the end-user energy utilization, fuel switching, nuclear energy, large scale deployment of Carbon Capture, Utilization and Storage (CCUS) technologies [2].

Among the most important two energy conversion concepts (based on fuel total and partial oxidation methods), the partial oxidation (PO) systems have significant advantages [3-5] e.g. lower effort to introduce the carbon capture (due to higher $\mathrm{CO}_{2}$ partial pressure in syngas compared with flue gas), better overall energy efficiencies, poly-generation capabilities (ability of the plant to produce simultaneously various energy carriers e.g. power, hydrogen, methanol, synthetic methane etc.). Two main partial oxidation systems are used: (i) catalytic reforming of hydrocarbons (gas or liquid) and (ii) solid fuel gasification. In PO designs, the conversion of carbon monoxide and steam to carbon dioxide and hydrogen is of paramount importance for a two-fold reason [6]: concentration of syngas energy as hydrogen and converting most of carbon species as $\mathrm{CO}_{2}$ to be later captured. The reaction of water gas shift (WGS) is the following:

$$
\mathrm{CO}+\mathrm{H}_{2} \mathrm{O} \leftrightarrow \mathrm{CO}_{2}+\mathrm{H}_{2}
$$

The WGS conversion of syngas can be done in various process configurations as evaluated in the present paper [7-9]. The assessments are geared towards the evaluation of process configurations on key plant performance indicators (e.g. overall energy efficiency, ancillary energy consumptions, carbon capture rate, specific $\mathrm{CO} 2$ emissions etc.) of various WGS conceptual designs. The assessed WGS process options are:

(i) Conventional catalytic conversion using 2-3 reactors in series either in clean shift conditions (with applications in natural gas reforming technologies) or sour shift conditions (with applications in coal gasification);

(ii) Iron looping (FeL) cycle using three interconnected circulated fluidized bed (CFB) reactors where the following reactions take place [10]:

- Syngas (fuel) reactor:

$$
\begin{aligned}
& 3 \mathrm{CO}+\mathrm{Fe}_{2} \mathrm{O}_{3} \rightarrow 3 \mathrm{CO}_{2}+2 \mathrm{Fe} \\
& 3 \mathrm{H}_{2}+\mathrm{Fe}_{2} \mathrm{O}_{3} \rightarrow 3 \mathrm{H}_{2} \mathrm{O}+2 \mathrm{Fe}
\end{aligned}
$$

- Steam reactor:

$$
3 \mathrm{Fe}+4 \mathrm{H}_{2} \mathrm{O} \rightarrow \mathrm{Fe}_{3} \mathrm{O}_{4}+4 \mathrm{H}_{2}
$$


ASSESSMENT OF VARIOUS WATER-GAS-SHIFT PROCESS CONFIGURATIONS APPLIED TO

PARTIAL OXIDATION ENERGY CONVERSION PROCESSES WITH CARBON CAPTURE

- Air reactor:

$2 \mathrm{Fe}_{3} \mathrm{O}_{4}+1 / 2 \mathrm{O}_{2} \rightarrow 3 \mathrm{Fe}_{2} \mathrm{O}_{3}$

(iii) Calcium looping (CaL) cycle using two interconnected circulated fluidized bed (CFB) reactors where calcium-based sorbent is used to move the WGS equilibrium to the right according to the following reactions [10]:

- Carbonation (sorption enhanced water gas shift) reactor:

$\mathrm{CO}+\mathrm{H}_{2} \mathrm{O}+\mathrm{CaO} \rightarrow \mathrm{CaCO}_{3}+\mathrm{H}_{2}$

- Calcination reactor:

$\mathrm{CaCO}_{3} \rightarrow \mathrm{CaO}+\mathrm{CO}_{2}$

As can be observed, both above mentioned high temperature looping cycles have as global WGS reaction as for catalytic case.

As illustrative case studies, this paper is assessing coal gasification as partial oxidation energy conversion system in conjunction with the above mentioned WGS configurations for hydrogen and power generation with carbon capture using reactive gas-liquid and gas-solid systems. The main novelty of this paper is relating to the evaluation of WGS systems based on chemical and calcium looping technologies for improved energy efficiency.

\section{PLANT CONFIGURATIONS AND MAIN DESIGN ASSUMPTIONS}

The Integrated Gasification Combined Cycle (IGCC) is a power generation technology in which the solid fuel is gasified with oxygen and steam to produce syngas [11]. After desulphurization, the syngas is used in a Combined Cycle Gas Turbine (CCGT) for power generation. When carbon capture step is integrated into an IGCC plant, WGS reaction has the purpose to concentrate the syngas energy as hydrogen as well as carbon species as $\mathrm{CO}_{2}$ [12-14]. The conceptual design of IGCC plant for hydrogen and power co-generation with carbon capture using conventional catalytic WGS conversion and gas-liquid absorption is presented in Figure 1.

In this design, the mixture of hydrogen and carbon dioxide resulted after WGS conversion is fed to the Acid Gas Removal (AGR) unit where using a reactive gas-liquid absorption (e.g. Methyl-DiEthanol-Amine - MDEA) $\mathrm{CO}_{2}$ is captured. The resulted hydrogen-rich gas can be either used in a combined cycle block for power generation or / and purified by Pressure Swing Adsorption for producing 99.95\% (vol.) hydrogen stream (either for external customers of for energy storage purposes). 


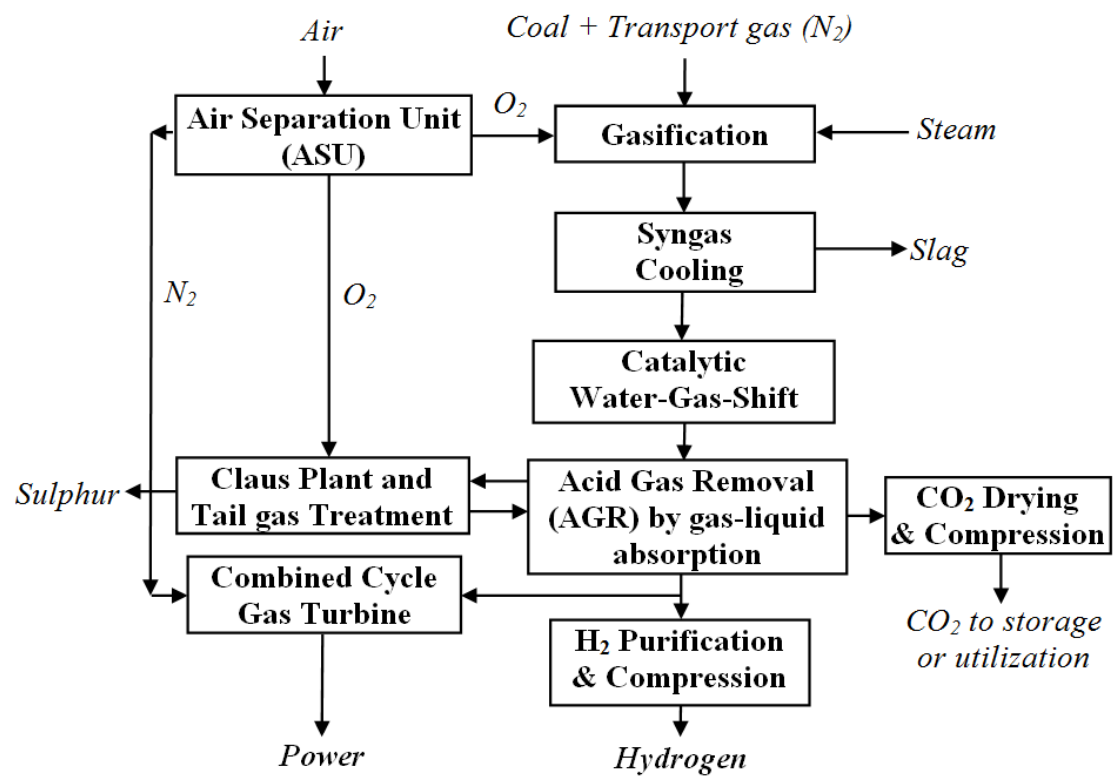

Figure 1. Design of IGCC plant with conventional catalytic WGS conversion

The other two investigated WGS concepts (based on FeL and CaL cycles) are using a more innovative technique - high temperature solid looping to convert the fuel (syngas) simultaneous with $\mathrm{CO}_{2}$ capture. For illustration, Figure 2 presents the conceptual design of Sorption Enhanced Water Gas Shift (SEWGS) unit using calcium-based material [15-16].

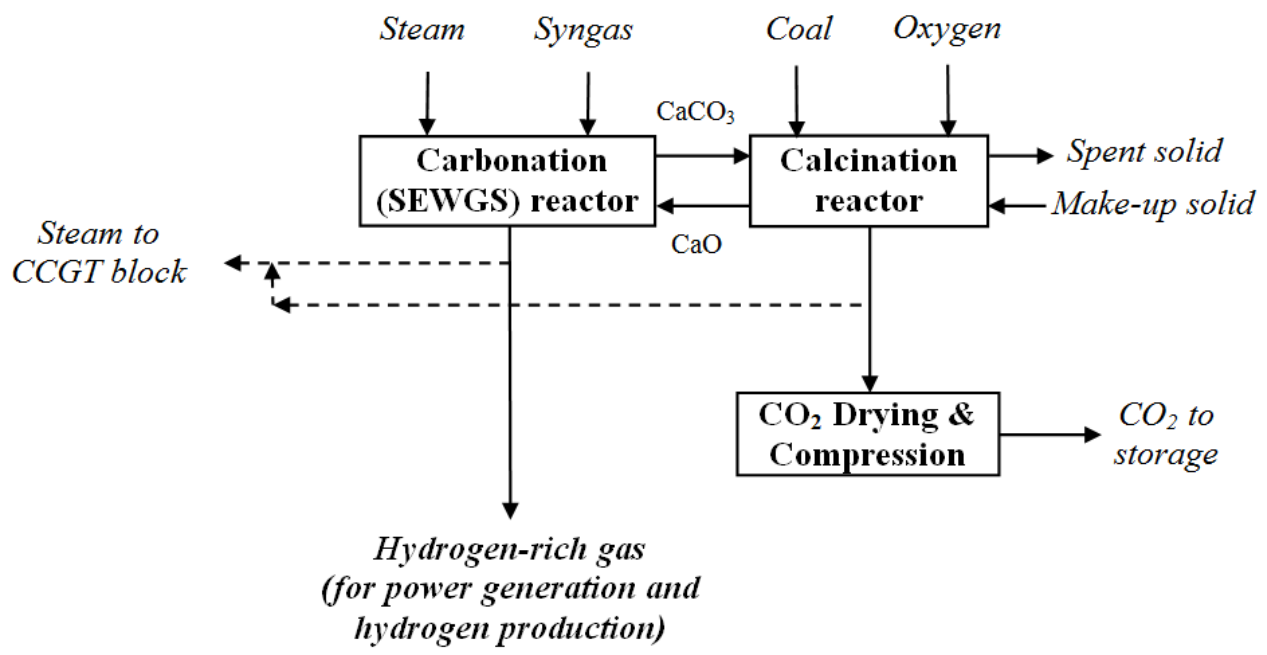

Figure 2. Design of carbon capture unit using CaL - SEWGS cycle 
In term of fuel, all cases used an international trade high grade coal sort (Douglas Premium). As gasification reactor considered in all designs, the dry fed syngas boiler configuration was chosen considering the high energy efficiency and low syngas clean-up issues [11]. Also, in term of gas turbine selection, a Mitsubishi Hitachi Power Systems - M701G2 was chosen for all evaluated cases considering its good industrial experience in processing hydrogen-rich gases as well as high energy efficiency and operational flexibility. The following IGCC with carbon capture (based on reactive gas-liquid and gas-solid systems) cases were assessed:

Case 1: IGCC plant with conventional catalytic WGS reactors and MDEA-based gas-liquid absorption for $\mathrm{CO}_{2}$ capture;

Case 2: IGCC plant with syngas-based iron looping cycle;

Case 3: IGCC plant with syngas-based calcium looping cycle.

The main design assumptions used in the modelling and simulation of the above mentioned concepts are presented in Table 1 [3,13,17-18].

Table 1. Main design assumptions of assessed IGCC case studies (Cases 1 - 3)

\begin{tabular}{|c|c|}
\hline Unit & Parameters \\
\hline Air Separation Unit (ASU) & $\begin{array}{l}\text { Oxygen purity (vol.): } 95 \% \mathrm{O}_{2}, 3 \% \mathrm{Ar}, 2 \% \mathrm{~N}_{2} \\
\text { ASU power consumption: } 195 \mathrm{kWh} / \text { ton oxygen }\end{array}$ \\
\hline Gasification reactor & $\begin{array}{l}\text { Oxygen / coal ratio }(\mathrm{kg} / \mathrm{kg}): 0.85 \\
\text { Steam / coal ratio }(\mathrm{kg} / \mathrm{kg}): 0.11 \\
\text { Nitrogen / coal ratio }(\mathrm{kg} / \mathrm{kg}): 0.10 \\
\text { Gasifier pressure: } 40 \mathrm{bar} \\
\text { Gasifier temperature: } \sim 1450^{\circ} \mathrm{C} \\
\text { Fuel conversion: }>99 \%\end{array}$ \\
\hline Catalytic WGS conversion & $\begin{array}{l}\text { Sulphur tolerant catalyst (sour shift) } \\
\text { Two adiabatic catalytic beds } \\
\text { Pressure drop: } 1 \text { bar / bed }\end{array}$ \\
\hline $\begin{array}{l}\text { Acid Gas Removal - AGR } \\
\text { (all cases - desulphurisation) }\end{array}$ & $\begin{array}{l}\text { Solvent: aqueous MDEA solution ( } 50 \% \text { mass) } \\
\text { Thermal solvent regeneration }\end{array}$ \\
\hline Iron looping (FeL) cycle & $\begin{array}{l}\text { Fuel reactor: } 31.5 \text { bar } / 750-900^{\circ} \mathrm{C} \\
\text { Steam reactor: } 30 \text { bar } / 700-800^{\circ} \mathrm{C} \\
\text { Air reactor: } 29 \text { bar / } 800-1000^{\circ} \mathrm{C} \\
\text { Gibbs free energy minimization model } \\
\text { Pressure drops: } 1 \text { bar / reactor }\end{array}$ \\
\hline Calcium looping (CaL) cycle & $\begin{array}{l}\text { Carbonation reactor: } 32 \text { bar } / 550-600^{\circ} \mathrm{C} \\
\text { Calcination reactor: } 31 \text { bar / } 900-980^{\circ} \mathrm{C} \\
\text { Gibbs free energy minimization model } \\
\text { Pressure drops: } 1 \text { bar / reactor }\end{array}$ \\
\hline $\mathrm{CO}_{2}$ compression and drying & $\begin{array}{l}\mathrm{CO}_{2} \text { delivery pressure at plant gate: } 120 \text { bar } \\
\text { Compressor efficiency: } 85 \% \\
\text { Solvent used for drying: Tri-ethylene-glycol }\end{array}$ \\
\hline
\end{tabular}




\begin{tabular}{|c|c|}
\hline Unit & Parameters \\
\hline Gas turbine & $\begin{array}{l}1 \text { x Mitsubishi Hitachi Power Systems - M701G2 } \\
\text { Gas turbine net power output: } 334 \mathrm{MW} \\
\text { Heat rate: } 9110 \mathrm{~kJ} / \mathrm{kWh} \text { (net efficiency: } 39.5 \% \text { ) } \\
\text { Compressor pressure ratio: } 21 \\
\text { Turbine outlet temperature (TOT): } 587^{\circ} \mathrm{C}\end{array}$ \\
\hline $\begin{array}{c}\text { Heat Recovery Steam } \\
\text { Generator (HRSG) and steam } \\
\text { cycle (Rankine) }\end{array}$ & $\begin{array}{l}\text { Three pressure levels: } 120 \text { / } 35 \text { / } 3 \text { bar } \\
\text { MP steam reheat } \\
\text { Steam turbine isoentropic efficiency: } 85 \% \\
\text { Steam wetness ex. steam turbine: max. } 10 \%\end{array}$ \\
\hline Heat exchangers & $\begin{array}{l}\Delta \operatorname{Tmin} .=10^{\circ} \mathrm{C} \\
\text { Pressure drop: } 2-5 \% \text { of inlet pressure }\end{array}$ \\
\hline
\end{tabular}

\section{RESULTS AND DISCUSSIONS}

The evaluated IGCC plant concepts were modeled and simulated using ChemCAD software, the generated mass and energy balances being used for quantification of main key performance indicators. For overall plant energy efficiency optimization (targeting especially WGS unit), all evaluated designs were thermally integrated using pinch methodology [19-20]. For illustration, Figure 3 presents the hot and cold composite curves for all three investigated WGS configurations along with syngas treatment line.

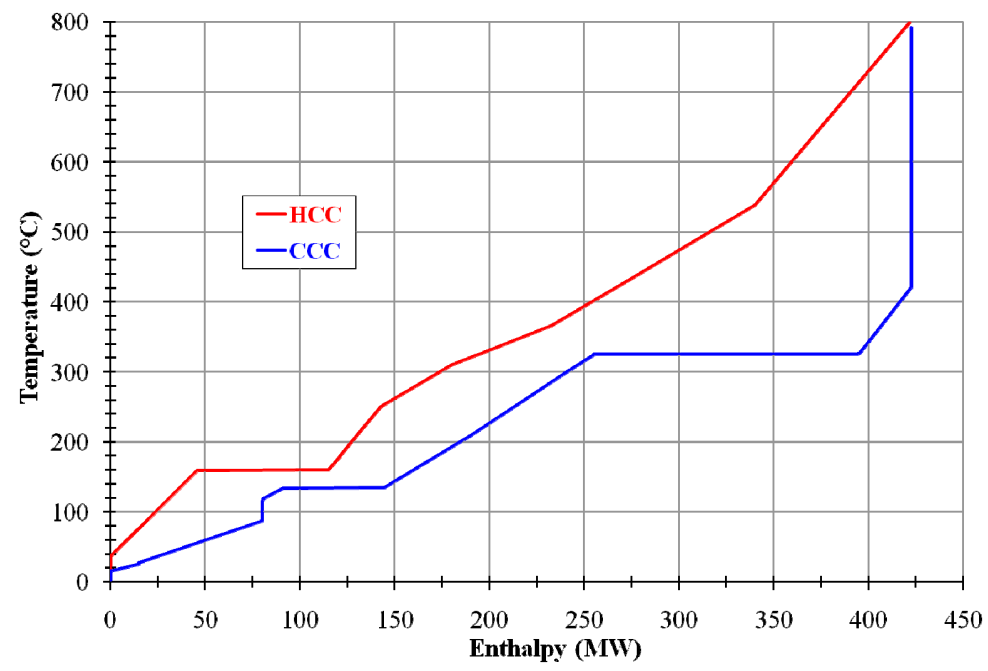

Figure 3.a. Composite curves for catalytic WGS reactors (Case 1) 


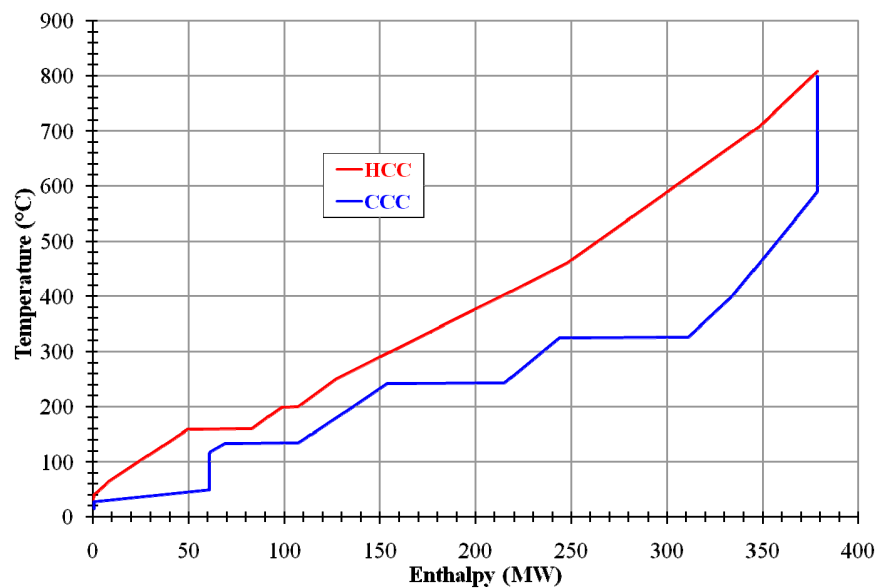

Figure 3.b. Composite curves for iron looping cycle (Case 2)

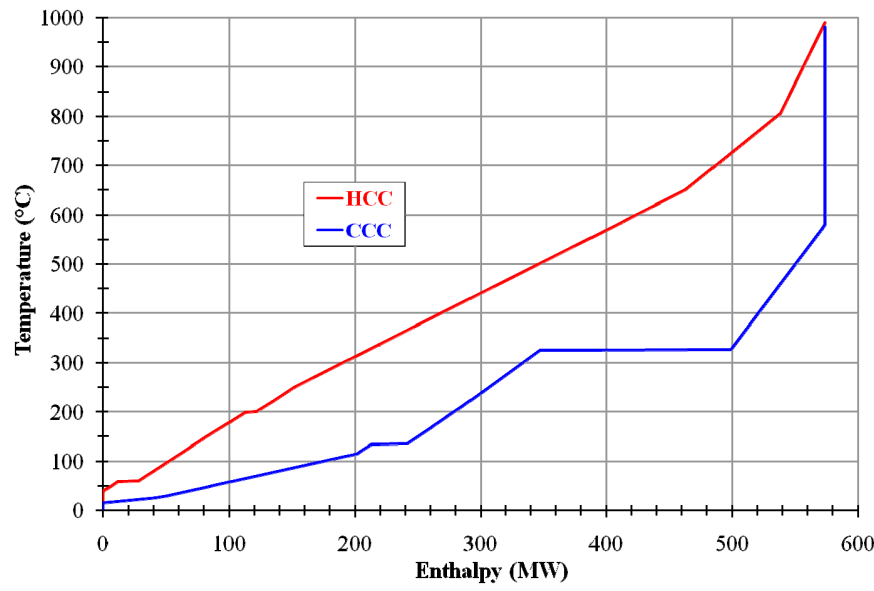

Figure 3.c. Composite curves for chemical looping cycle (Case 3)

An important aspect to be mentioned is that for the chemical looping cases, the operating temperatures of looping reactors are significantly higher than for gas-liquid absorption (operated around atmospheric temperature). As can be observed from Figure 3, for iron looping case (Case 2), more heat is recovered as MP steam compared to Cases 1 and 3. Also, when compare the looping cases, one can noticed that the thermal integration in Case 2 (FeL) is better (hot and cold composite curves are closer) than for Case 3 (CaL). These aspects will have an important influence on overall energy efficiency of the plant as presented below. 
Table 2 presents the main performance indicators of evaluated IGCC with carbon capture designs operated in power generation only.

Table 2. Overall plant performance indicators - power generation only

\begin{tabular}{|c|c|c|c|c|}
\hline Main Plant Data & Units & Case 1 & Case 2 & Case 3 \\
\hline Coal flowrate (as received) & $\mathrm{t} / \mathrm{h}$ & 165.00 & 162.00 & 225.00 \\
\hline Coal LHV (as received) & $\mathrm{MJ} / \mathrm{kg}$ & \multicolumn{3}{|c|}{25.353} \\
\hline Coal thermal energy $(A)$ & $\mathrm{MW}_{\mathrm{th}}$ & 1162.00 & 1140.88 & 1584.56 \\
\hline Gas turbine output (M701G2) & $\mathrm{MW}_{\mathrm{e}}$ & 334.00 & 334.00 & 334.00 \\
\hline Steam turbine output & $\mathrm{MWe}_{\mathrm{e}}$ & 201.25 & 200.00 & 411.25 \\
\hline Expander power output & $\mathrm{MW}_{\mathrm{e}}$ & 1.01 & 1.25 & 1.40 \\
\hline Gross electric power output (B) & $\mathrm{MW}_{\mathrm{e}}$ & 536.26 & 535.25 & 746.65 \\
\hline Ancillary consumption $(\mathrm{C})$ & $\mathrm{MW}$ & 110.67 & 95.75 & 152.82 \\
\hline Net power output (D = B - C) & $\mathrm{MW}_{\mathrm{e}}$ & 425.59 & 439.50 & 593.83 \\
\hline Gross efficiency $(\mathrm{B} / \mathrm{A} * 100)$ & $\%$ & 46.15 & 46.91 & 47.12 \\
\hline Net efficiency $(\mathrm{D} / \mathrm{A} * 100)$ & $\%$ & 36.62 & 38.52 & 37.47 \\
\hline Carbon capture rate & $\%$ & 90.00 & 99.00 & 96.00 \\
\hline $\mathrm{CO}_{2}$ specific emissions & $\mathrm{kg} / \mathrm{MWh}_{\mathrm{e}}$ & 83.24 & 4.10 & 33.50 \\
\hline
\end{tabular}

The high temperature looping cases (FeL and $\mathrm{CaL}$ ) have superior overall net efficiency (by about 0.9 - 1.9 points) and carbon capture rate (90\% vs. $96-99 \%)$ than conventional WGS catalytic conversion coupled with reactive gas-liquid absorption for $\mathrm{CO}_{2}$ capture. These results show the good potential of chemical looping technology (which simultaneously convert the syngas energy in a decarbonised energy carrier - hydrogen and capture carbon from syngas) to replace in the future the conventional technologies (catalytic WGS conversion and gas-liquid absorption).

Ancillary energy consumption of carbon capture unit is a factor with paramount importance in any CCUS design. In this respect, the reactive gas-liquid systems (as exemplified here by MDEA-based system) have a clear disadvantage by the significant heat duty required to regenerate the solvent (about $3 \mathrm{MJ} / \mathrm{kg} \mathrm{CO}$ ). To evaluate in a holistic manner the ancillary energy consumption for $\mathrm{CO}_{2}$ capture, one can use primary energy consumption for $\mathrm{CO}_{2}$ avoided (SPECCA) calculated as follow [21]:

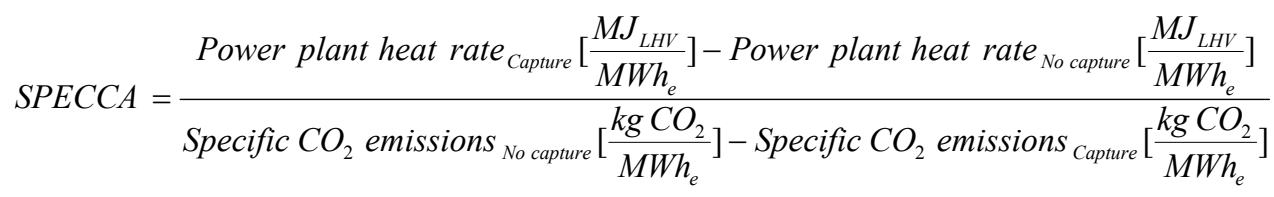


For an IGCC power plant benchmark case without capture, key literature references (e.g. IEAGHG, NETL reports) were used [14,22]. The SPECCA values calculated for the investigated concepts (Cases 1 to 3 ) are: $2.75,1.88$ and respectively $2.36 \mathrm{MJ} / \mathrm{kg}$. As also showed by SPECCA indicator, the reactive gas-solid systems (FeL and $\mathrm{CaL}$ cycles) have lower energy consumptions for $\mathrm{CO}_{2}$ capture than the reactive gas-liquid system.

An important feature of gasification plants coupled with pre-combustion $\mathrm{CO}_{2}$ capture (exhibits here by all investigated concepts) is the ability of hydrogen and power co-generation [23-25]. These plants can generate (according to the instant power demand from the grid) either only electricity (peak times), hydrogen and power (transient times) or only hydrogen for energy storage (when power generation is low). This operational flexibility can be obtained by a simple operational procedure - the gas turbine is gradually turned down to displace a hydrogen stream for purification and then energy storage. To illustrate the ability of hydrogen and power co-generation, Table 3 presents the variation of performance indicators with hydrogen produced (in the range $0-200 \mathrm{MW}_{\text {th }}$ ) for Case 2.

Table 3. Overall plant performance indicators - hydrogen and power co-generation

\begin{tabular}{|c|c|c|c|c|}
\hline Main Plant Data & Units & Power & \multicolumn{2}{|c|}{ Hydrogen and power } \\
\hline Coal flowrate as received) & $\mathrm{t} / \mathrm{h}$ & \multicolumn{3}{|c|}{162.00} \\
\hline Coal LHV (as received) & $\mathrm{MJ} / \mathrm{kg}$ & \multicolumn{3}{|c|}{25.353} \\
\hline Coal thermal energy $(A)$ & $\mathrm{MW}_{\mathrm{th}}$ & \multicolumn{3}{|c|}{1140.88} \\
\hline Gas turbine output (M701G2) & $\mathrm{MW}$ & 334.00 & 294.28 & 253.10 \\
\hline Steam turbine output & $\mathrm{MW}_{\mathrm{e}}$ & 200.00 & 181.01 & 162.24 \\
\hline Expander power output & $\mathrm{MW}_{\mathrm{e}}$ & 1.25 & 1.20 & 1.15 \\
\hline Gross electric power output (B) & $\mathrm{MW}_{\mathrm{e}}$ & 535.25 & 476.49 & 416.49 \\
\hline Hydrogen output (C) & $\mathrm{MW}_{\text {th }}$ & 0.00 & 100.00 & 200.00 \\
\hline Ancillary consumption (D) & $\mathrm{MW}_{\mathrm{e}}$ & 95.75 & 94.33 & 92.84 \\
\hline Net power output $(E=B-D)$ & $\mathrm{MW}_{\mathrm{e}}$ & 439.50 & 382.16 & 323.65 \\
\hline Net efficiency $(E / A * 100)$ & $\%$ & 38.52 & 33.49 & 28.36 \\
\hline Hydrogen efficiency $(\mathrm{C} / \mathrm{A} * 100)$ & $\%$ & 0.00 & 8.76 & 17.53 \\
\hline Cumulative energy efficiency & $\%$ & 38.52 & 42.25 & 45.89 \\
\hline Carbon capture rate & $\%$ & 99.00 & 99.00 & 99.00 \\
\hline $\mathrm{CO}_{2}$ specific emissions & $\mathrm{kg} / \mathrm{MWh}$ & 4.10 & 3.73 & 3.44 \\
\hline
\end{tabular}

As can be noticed, the hydrogen and power co-generation have a positive influence on overall (cumulative) plant energy efficiency, this indicator increasing with the hydrogen output by about 3.7 net cumulative efficiency point for each $100 \mathrm{MW}_{\text {th }}$ hydrogen produced. Other positive changes can be observed: slight decrease of ancillary energy consumption (by about $1.5 \mathrm{MW}_{\mathrm{e}}$ 
per each $100 \mathrm{MW}_{\text {th }}$ hydrogen) and specific $\mathrm{CO}_{2}$ emissions (considering the total plant energy produced). In addition to the technical performance indicators, the economic indicators (e.g. specific capital investments, operational \& maintenance cost, $\mathrm{CO}_{2}$ avoidance costs etc.) are also improving with hydrogen coproduction [25]. The development of flexible hydrogen production systems with low carbon emissions (as evaluated in this work) are of great importance for a sustainable development of key fossil fuel-dependent industrial sectors e.g. heat and power, transport, petro-chemistry, metallurgy etc. [26-27].

\section{CONCLUSIONS}

This paper evaluates three water-gas-shift (WGS) process configurations used in connection with a coal-based IGCC power plant with carbon capture as follow: (i) conventional multi-catalytic reactors coupled with reactive gas-liquid absorption; (ii) iron looping cycle and (iii) sorbent enhanced chemical looping cycle. As the results show, the looping cycles have significant advantages compared to conventional design e.g. higher overall plant energy efficiency (by about $0.9-1.9$ net efficiency points), higher carbon capture rate (96$99 \%$ vs. 90\%) and lower SPECCA values (by about $0.4-0.9 \mathrm{MJ} / \mathrm{kg}$ ). The hydrogen and power co-generation based on IGCC design with carbon capture has also significant operational advantages: better plant flexibility (cycling), higher overall (cumulative) efficiency (3.7 net energy efficiency points per each $100 \mathrm{MW}_{\text {th }}$ hydrogen), better techno-economic indicators.

\section{ACKNOWLEDGMENTS}

This work was supported by a grant of the Romanian National Authority for Scientific Research, CNCS - UEFISCDI, project ID PN-III-P4-ID-PCE-2016-0031: "Developing innovative low carbon solutions for energy-intensive industrial applications by Carbon Capture, Utilization and Storage (CCUS) technologies".

\section{REFERENCES}

1. European Commission, "A policy framework for climate and energy in the period from 2020 to 2030", COM(2014) 15 final, Brussels, Belgium, 2014.

2. B. Metz, O. Davidson, H. de Coninck, M. Loos, L. Meyer, "Carbon Dioxide Capture and Storage", Intergovernmental Panel on Climate Change (IPCC), Geneva, Switzerland, 2005.

3. A. M. Cormos, C. Dinca, C. C. Cormos, Applied Thermal Engineering, 2015, 74, 20.

4. R. Segurado, S. Pereira, D. Correia, M. Costa, Renewable and Sustainable Energy Reviews, 2019, 103, 501. 
ASSESSMENT OF VARIOUS WATER-GAS-SHIFT PROCESS CONFIGURATIONS APPLIED TO PARTIAL OXIDATION ENERGY CONVERSION PROCESSES WITH CARBON CAPTURE

5. T. A. Adams, P. I. Barton, Fuel Processing Technology, 2011, 92, Issue 3, 639.

6. A. I. Papadopoulos, P. Seferlis, "Process systems and materials for $\mathrm{CO}_{2}$ capture Modelling, design, control and integration", John Wiley \& Sons Ltd., 2017, chapter 11.

7. S. Saeidi, F. Fazlollahi, S. Najari, D. Iranshahi, J. J. Klemeš, L. Baxter, Journal of Industrial and Engineering Chemistry, 2017, 49, 1.

8. K. Liu, C. Song, V. Subramani, "Hydrogen and syngas production and purification technologies", AIChE - Wiley, Inc., 2010, chapter 6.

9. C. C. Cormos, A. M. Cormos, L. Petrescu, Chemical Engineering Research and Design, 2014, 92, 741.

10. L. S. Fan, "Chemical looping systems for fossil energy conversions", AIChE Wiley, Inc. 2010, chapter 1.

11. C. Higman, M. van der Burgt, "Gasification", second ed., Gulf Professional Publishing, Elsevier Science, 2008.

12. B. Shi, W. Xu, E. Wu, W. Wu, P. C. Kuo, Journal of Cleaner Production, 2018, 195, 176.

13. C. C. Cormos, Energy, 2012, 42, 434.

14. International Energy Agency - Greenhouse gas R\&D programme (IEAGHG), "Potential for improvement in gasification combined cycle power generation with $\mathrm{CO}_{2}$ capture", Report PH4/19, Cheltenham, UK, 2003.

15. W. Wu, F. Wen, J. R. Chen, P. C. Kuo, B. Shi, Journal of the Taiwan Institute of Chemical Engineers, 2019, 96, 193.

16. D. P. Hanak, S. Michalski, V. Manovic, Energy Conversion and Management, 2018, 177, 428.

17. U. Ahmed, U. Zahid, Y. Lee, International Journal of Hydrogen Energy, 2019, $44,7137$.

18. A. M. Cormos, C. C. Cormos, International Journal of Hydrogen Energy, 2014, 39, 2067.

19. W. Xu, B. Shi, W. Wu, Energy Procedia, 2018, 152, 1248.

20. J. A. R. Diamante, R. Tan, D. C..Y. Foo, D. K. S. Ng, K. B. Aviso, S. Bandyopadhyay, Journal of Cleaner Production, 2014, 71, 67.

21. A. M. Cormos, C. Dinca, L. Petrescu, D. A. Chisalita, S. Szima, C.C. Cormos, Fuel, 2018, 211, 883.

22. National Energy Technology Laboratory (NETL), "Cost and performance baseline for fossil energy plants - Volume 1: Bituminous coal and natural gas to electricity", Report 2010/1397, Albany, USA, 2010.

23. A. Zohrabian, M. M. Majoumerd, M. Soltanieh, S. Sattari, International Journal of Greenhouse Gas Control, 2016, 44, 94.

24. M. van der Spek, S. Roussanaly, E. S. Rubin, International Journal of Greenhouse Gas Control, 2019, 83, 91.

25. A. M. Cormos, C. C. Cormos, Applied Thermal Engineering, 2019, 147, 29.

26. A. Chapman, K. Itaoka, K. Hirose, F. T. Davidson, K. Nagasawa, A. C. Lloyd, M. E. Webber, Z. Kurban, S. Managi, T. Tamaki, M. C. Lewis, R. E. Hebner, Y. Fujii, International Journal of Hydrogen Energy, 2019, 44, 6371.

27. A. Ozawa, Y. Kudoh, A. Murata, T. Honda, I. Saita, H. Takagi, International Journal of Hydrogen Energy, 2018, 43, 18083. 